\title{
Technological Leadership Behavior Of High School Headteachers In Asir Region, Saudi Arabia
}

\author{
Mofareh Alkrdem, King Khalid University, Saudi Arabia
}

\begin{abstract}
The purpose of this study is to examine the technological leadership behaviors of Saudi Arabian high school regarding the supply and use of educational technologies based on the educational technology standards developed and approved for school headteachers in many countries. The study was carried out with 135 high school headteachers. In the study, the survey research design was used, and the research data were collected via a questionnaire. For the analysis of the data, ANOVA and t-tests were applied. The results indicated that the headteachers generally demonstrated a high level of technological leadership behavior, in general, in providing and using of educational technologies. In addition, the technological leadership behavior of the headteachers did not differ with respect to their gender, study field, level of education, and their experience in leadership.
\end{abstract}

Keywords: Technological Leadership; Educational Technology Standards; School Headteachers

\section{INTRODUCTION}

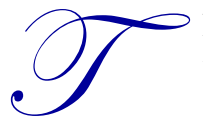

he school systems in the world are increasingly under pressure regarding the use of technology in the teaching-learning and management processes (Gurr, 2001). The expectations of students and of parents are increasing day by day. Educational institutions admit students who are acquainted with satellite receivers and use mobile phones, CD-DVD players, and computers in their daily lives (Aksoy, 2003). The teaching-learning and management process is transferred into a network environment via online systems, such as e-school. In this way, teachers, students, and parents can now reach information sources easily. Thus, the importance of educational technologies is increasing with each passing day. There is no clear definition of school headteachers' duties regarding their technological leadership in schools, yet it is apparent that they are responsible for technological applications in schools. Therefore, the International Society for Technology in Education-ISTE published the standards that define the school headteachers' roles in educational technology use in schools (ISTE, 2002). In addition, ISTE also published national educational technology standards for other sharers in the educational process, such as students and teachers. These standards were updated for students in 2007, for teachers in 2008, and for administrators in 2009 (ISTE, 2009).

The National Education Technology Standards called NETS standardize the qualifications and proficiencies that teachers, students, and school headteachers should have regarding educational technology use. NETS, with its dimensions for teachers (NETS-T), for students (NETS-S), and for administrators (NETS-A), could be taken as basis for determining the standards regarding the supply and use of educational technologies in Saudi.

According to the NETS-A standards, the goal is to train school headteachers who have understood the school model in information society to start, to implement, and to manage the changes in schools; who can meet the complex needs of schools via technological sources; who can find ways to increase the productivity in the new structure of the school; and who can make decisions regarding the future of the institution. Within the scope of these standards, the skills and knowledge that all school headteachers - including elementary and high- 
school headteachers - should have to become effective leaders in technological applications are defined via 31 performance indicators and six standard areas (ISTE, 2002).

In the study conducted by Yu and Durrington (2006) on candidate school headteachers and experienced school headteachers, it was found out that school headteachers demonstrated an average level of technological leadership behavior according to the scope of NETS-A standards; that the candidate school headteachers received the highest score in the area of teaching-learning; and that the experienced school headteachers received the highest score in the area of social, legal, and ethical issues. According to the result of another study conducted by Persaud (2006), school headteachers were found to be inefficient in educational technologies and to be in need of personal development in all the dimensions of NETS-A standards.

NETS standards, which are directly approved or adapted by a number of countries, have been transformed into national educational technology standards. They could also constitute the basis of educational technology use in Saudi. School headteachers have a key role in Saudi Arabia in terms of the investments made by the Ministry of Education on the supply of educational technologies for schools and in terms of the activities organized for effective use of these investments. Thus, the present study is important since it aims at determining to what extent school headteachers can achieve their expected tasks with respect to certain variables.

\section{METHOD}

\section{Research Model}

The study was carried out with the use of singular and correlational survey methods.

\section{Purpose of the Study}

The basic purpose of the study was to determine high school headteachers' technological leadership behavior regarding the supply and use of educational technologies in high schools. For this purpose, the following research questions were directed:

- In the process of supply and use of educational technologies in their schools, to what extent do high school headteachers demonstrate technological leadership behavior within the scope of such areas of standards as technological leadership and vision; teaching and learning process; productivity and professional development; support, management and processes; measurement and evaluation; social, legal and ethical issues?

- Do high school headteachers' technological leadership behaviors regarding the supply and use of educational technologies in their schools differ significantly with respect to their gender, their level of education, their experience in school headteachership, and their use of these technologies and their evaluation of their proficiency in educational technology use?

\section{Population and Sample}

The general population of the study, conducted with a survey model, was made up of 135 school headteachers working in the Ministry of Education high schools in Asir region, Saudi Arabia, in the 2012-2013 academic year (Ministry of Education, 2013). The data collected from a total of 135 school headteachers, which constitutes the sample, were analyzed. Participants included $95.3 \%(\mathrm{n}=129)$ male and $4.7 \%(\mathrm{n}=6)$ female. The majority of the headteachers $(65.1 \%, \mathrm{n}=128)$ had a bachelor's degree and the highest percentage of headteachers $(31.5 \%, \mathrm{n}=83)$ had $1-5$ years of headteacher experience.

\section{Data Collection Tool}

The questionnaire used in the study was developed by the researcher based on the areas of NETS-A standards that define the knowledge and skills that school headteachers need to become effective leaders in the 
use of educational technologies in their schools. Five experts from the fields of educational technologies, educational management and statistics were asked for their views about the questionnaire. Then, the pilot study of the questionnaire was conducted. Following the suggestions of experts and the preliminary applications, certain corrections and changes were made on the data collection tool, and the questionnaire was made ready for use for data collection.

\section{Data Analysis}

In the study, descriptive statistics were applied for the analysis of the questions directed to reveal background information about the school headteachers participating in the study, to determine whether they received trainings on educational technologies, and to reveal information about their use of these technologies and about their evaluations of their own proficiency in educational technology use. The level of the school headteachers' leadership behavior was evaluated via their responses to each question. In addition, the limits determined according to the coefficient $(4 / 5=0.80)$ calculated for each range $(5-1=4)$ - with the assumption that the ranges in the questionnaire are equal - were determined as low (1.00-2.60), average (2.61-3.40), and high (3.41-5.00). All related interpretations were made according to this range. In line with the study goals, a ttest and one-way analysis of variance (ANOVA) were run.

\section{FINDINGS}

The findings obtained as a result of the statistical analyses of the data collected in line with the research purposes are summarized below.

The first research question of the study was directed to reveal to what extent school headteachers demonstrated leadership behavior - in the process of the supply and use of educational technologies in their schools regarding such areas of standards as technological leadership and vision, teaching and learning process, productivity and professional development, support, management and processes, evaluation, social, legal and ethical issues.

First of all, the school headteachers' leadership behavior, regarding the supply and use of educational technologies, was revealed. For this purpose, the mean of the responses given by the school headteachers to the statements in the data collection tool regarding the use of educational technologies was calculated as 3.84 . Table 1 shows the levels of the school headteachers' leadership behavior.

Table 1: The Levels of the School Headteachers' Leadership Behavior

\begin{tabular}{|c|c|c|c|c|c|}
\hline \multicolumn{2}{|c|}{ Low Level } & \multicolumn{2}{c|}{ Average Level } & \multicolumn{2}{c|}{ High Level } \\
\hline $\mathbf{n}$ & \% & n & \% & n & \% \\
\hline 4 & 2.89 & 17 & 11.79 & 111 & 85.31 \\
\hline
\end{tabular}

It is seen that most of the school headteachers demonstrated in the process of supply and use of educational technologies was in the 'high level' category. Depending on this, it could be stated that the school headteachers generally demonstrated high level of leadership behavior regarding the supply and use of educational technologies.

\section{Technological Leadership Behavior in Terms of Leadership Areas}

When the mean of the leadership behavior that the school headteachers demonstrated in the process of supply and use of educational technologies is examined with respect to the leadership behavior standard areas, it is seen that the school headteachers had the highest mean for the dimensions of measurement and evaluation ( $\mathrm{X}$ $=4.12, \mathrm{sd}=.78)$, technological leadership and vision $(\mathrm{X}=4.11, \mathrm{sd}=.77)$, and the lowest mean for the dimension of support, management and processes $(X=3.36, \mathrm{sd}=.36)$. It could also be stated that the school headteachers demonstrated an average level of leadership behavior for the dimension of support, management and processes and high level of leadership behavior in all the other areas. 


\section{Technological Leadership Behavior in Terms of Gender}

In order to reveal whether the school headteachers' leadership behavior regarding the supply and use of educational technologies differed with respect to their gender, t-test was run. The school headteachers' leadership behavior in the process of supply and use of educational technologies did not differ with respect to their gender $(\mathrm{t}(133)=.866, \mathrm{p}>.05)$. In other words, male and female school headteachers demonstrated similar leadership behavior in the process of supply and use of educational technologies.

\section{Technological Leadership Behavior in Terms of Study Field, Educational Level, and Experience}

In order to determine whether the school headteachers' leadership behavior in the process of supply and use of educational technologies differed with respect to their study fields, educational level and experience in headteachership, ANOVA was applied. As a result of the analysis, there was no significant difference between the study fields of the school headteachers and their leadership behavior in the process of supply and use of educational technologies $(F[6-132]=.450, p>.05)$. In other words, the school headteachers with different study fields demonstrated similar leadership behavior regarding the supply and use of educational technologies. Similarly, no significant difference was found between the school headteachers' education levels and their leadership behavior regarding the supply and use of educational technologies $(F[2-129]=.104, p>.05)$. That is, the school headteachers with different educational levels demonstrated similar leadership behavior. In addition, it was also revealed that there was no significant difference between the school headteachers' experience in school headteachership and their leadership behavior regarding the supply and use of educational technologies $(\mathrm{F}[4-113]=1.789, \mathrm{p}>.05)$. In other words, the level of the school headteachers' leadership behavior regarding the supply and use of educational technologies did not differ with respect to their experience in school headteachership.

\section{School Headteachers' Technological Leadership Behavior in Terms of Their Evaluation of Their Proficiency in Educational Technology Use}

In order to see whether the school headteachers' leadership behavior regarding the supply and use of educational technologies differed with respect to their evaluation of their proficiency in educational technology use, ANOVA was applied. The results obtained are presented in Table 2. When the table is examined, it is seen that there was a significant difference between the school headteachers' evaluation of their proficiencies in educational technology use and their technological leadership behavior $\left(\mathrm{F}_{[3 \cdot 116]}=14.784, \mathrm{p}<.05\right)$. In other words, the school headteachers' leadership behavior differed with respect to their evaluation of their proficiencies in technology use.

Table 2: School Headteachers' Technological Leadership Behavior in Terms of Their Evaluation of Their Proficiency in Educational Technology Use

\begin{tabular}{|c|c|c|c|}
\hline Source of Variance & F & P & Difference \\
\hline Evaluations of Their Proficiencies & 14.784 & .000 & A-D, B-D, A-C,A-B \\
\hline
\end{tabular}

A-Beginner, B Intermediate, C- Upper-Intermediate, D- Advanced

\section{DISCUSSION AND CONCLUSION}

In this study, it was found out that the school headteachers generally demonstrated a high level of leadership behavior regarding the supply and use of educational technologies. This finding is consistent with the findings reported in literature that school headteachers demonstrate a high level of technological leadership behavior (Chang, Chin, \& Hsu, 2008) and that school headteachers have a high level of leadership characteristics with respect to NETS-A standards (Weber, 2006). Similarly, the present finding is also parallel to the finding of a study conducted by Macaulay (2009) who reported that school headteachers generally consider themselves as proficient in demonstrating technological leadership behavior and to the finding of another study carried out by Kozloski (2007) who stated that school headteachers regard themselves as technological leaders. The findings of other studies carried out by Redish and Chan (2007), Anderson and Dexter (2005), and by Ertmer, Bai, Dong, Khalil, Park, and Wang (2002), who commonly reported that school headteachers play their technological leadership roles, also support the related findings of the present study. 
In this study, the finding that the school headteachers demonstrated a high level of leadership behavior regarding the supply and use of educational technologies differs from the findings of other studies carried out by $\mathrm{Yu}$ and Durrington (2006) who concluded that school headteachers have an average level of proficiency in educational technology applications. On the other hand, the findings of a study carried out by Persaud (2006), who reported that school headteachers are proficient in educational technology use, are also different from the findings of the present study.

In addition, it was concluded that another standard area in which the school headteachers had a high mean was 'leadership and vision.' This finding is similar to the findings of other studies reported in literature (Chang, Chin, \& Hsu, 2008; Yu \& Durrington, 2006) but differs from another study conducted by Persaud (2006) who reported that school headteachers do not have clear visions regarding their roles. The fact that the school headteachers had a high mean in this standard area could be explained with the fact that school headteachers are eager to use new technologies to increase the quality of education in their schools and that they take risk in such situations and communicate with other school headteachers to get informed about these technologies. Therefore, it could be stated that school headteachers are open to renovations regarding educational technology use and that they are in the transition period from the traditional understanding of education to modern understanding of education. Another reason why the school headteachers had a high mean in this standard area could be explained with the fact that they are familiar with the concepts of 'leadership' and 'vision' and that within the scope of studies on 'Total Quality Management' and 'School Development Management Team,' studies on 'vision' and 'mission' were carried out in many schools in the leadership of school headteachers in Saudi.

The fact that the school headteachers had the lowest mean in the standard area of 'support, management, and processes' was another finding obtained in the present study. This finding is consistent with the findings of studies conducted by Yu and Durrington (2006) who reported that school headteachers had the lowest mean in the standard area of support, management, and processes, and with the finding of another study carried out by Macaulay (2009), who reported that based on their perceptions, teachers considered school headteachers as weak in this standard area.

The school headteachers' leadership behavior regarding the supply and use of educational technologies did not differ with respect to their gender, study fields, educational level, or their experience in school headteachership. The finding that both male and female school headteachers demonstrated similar leadership behavior regarding the supply and use of educational technologies is parallel to the findings of other studies conducted by Dawson and Rakes (2003) and by Anderson and Dexter (2000). This result might have occurred due to the lack of a balanced distribution in sampling with respect to gender.

Another finding - that the level of school headteachers' leadership behavior regarding the supply and use of educational technologies did not differ with respect to their experience in school headteachership - is consistent with the findings of studies conducted by Macaulay (2009) and Dawson and Rakes (2003).

Furthermore, a significant relationship was found between the school headteachers' perceptions of their own proficiencies in technology use and their leadership behavior. In other words, school headteachers who feel themselves proficient in technology use demonstrate a high level of technological leadership behavior.

Based on the findings obtained in the present study, the following suggestions could be put forward:

- Sufficient education and support should be given to school headteachers regarding the use of educational technologies provided in schools.

- Units for technical counseling and support should be established within the body of National Education Headteachership in provinces for the supply of equipment and software for schools.

- School headteachers should be encouraged to participate in post-graduate education programs regarding school leadership.

- Cooperation should be made with universities for the organization of pre-service and in-service trainings on school headteachers' educational technology use.

- School headteachers' technological leadership skills should be taken into account for their appointment. 


\section{AUTHOR INFORMATION}

Dr. Mofareh Alkrdem is the chairman of Education Department at King Khalid University. He received his undergraduate degree in Islamic Law from King Khalid University, Saudi Arabia in1999. Alkrdem obtained his Master degree in Education from Troy State University, USA in 2006, and he completed his $\mathrm{PhD}$ in Education at The University of York, UK in 2012. He then joined the College of Education at King Khalid University in 2012. $\mathrm{He}$ is interested in educational leadership and educational planning. E-mail: msalkerdem@kku.edu.sa

\section{REFERENCES}

1. Aksoy, H. H. (2003). Analysis of technology use in educational institutions and of its effects. Education Science and Society. 1(4), 4-23.

2. Anderson, R. E., \& Dexter, S. (2000). School technology leadership: Incidence and impact. Center for Research on Information Technology and Organizations, IT in Education, Retrieved 15 May, 2012 from www.crito.uci.edu/tlc/findings/report_6/report_6.pdf

3. Chang, H., Chin, J. M., \& ve Hsu, C. M. (2008). Teachers perceptions of the dimensions and implementation of technology leadership of headteachers in Taiwanese schools. Educational Technology \& Society, 11(4), 229-245. Retrieved August 7, 2012 from http://www.ifets.info/journals/11_4/14.pdf

4. Dawson, C., \& Rakes, G. C. (2003). Technology training on the integration of technology into schools. Journal of Research on Technology in Education, 56(1).

5. $\quad$ Ertmer, P. A., Bai, H., Dong, C., Khalil, M., Park, S. H., \& Wang, L. (2002). Technology leadership: Shaping administrators' knowledge and skills through an online professional development course. Retrieved 03 February 2013 from http://www.edci.purdue.edu/ertmer/docs/SITE02_TIPDOC_paper.PDF

6. Gurr, D. (2001). Principals, technology and change. The Technology Source Archives. University of North Carolina. Retrieved 28 July, 2012 from http://technologysource.org/article/headteachers _technology_and_change

7. International Society for Technology in Education. (2002). National educational technology standards for administrators. Retrieved 05 April, 2012 from http://www.iste.org/Content/NavigationMenu/NETS/ ForAdministrators/2002Standards/NETS_for_Administrators_2002_Standards.htm

8. International Society for Technology in Education. (2009). National educational technology standards for administrators. Retrieved 10 September, 2012 from http://www.iste.org/Content/NavigationMenu /NETS/ForAdministrators/2009Standards/NETS_for_Administrators_2009.htm

9. Kozloski, K. C. (2007). Principal leadership for technology integration: A study of headteacher technology leadership. (Unpublished doctoral dissertation). Drexel University, United States. Retrieved 2 March, 2013 from http://www.iste.org/Content/NavigationMenu/Research/NECC_Research_Paper_ Archives/NECC_2007/Kozloski_Kristen_N07.pdf

10. Macaulay, L. S. (2009, June). Elementary principals as technology instructional leaders. Towson University, Department of Instructional Technology and Literacy. Research paper presented at NECC. Retrieved August, 28, 2012 from http://www.iste.org/Content/NavigationMenu/Research/NECC_ Research_Paper_Archives/NECC2009/Macaulay_NECC09.pdf

11. Ministry of Education. (2012). National Education Statistics, formal education. Retrieved 12 June, 2012 from http://www.moe.gov.sa/pages/stats_summary.aspx

12. Persaud, B. (2006). School administrators' perspective on their leadership role in technology integration. Yayinlanmamis, Walden University, United States.

13. Redish, T., \& Chan, T. C. (2007). Technology leadership: Aspiring administrators' perceptions of their leadership preparation program. Electronic Journal for the Integration of Technology in Education, 6, 123-139.

14. Weber, M. J. (2006). Study of computer technology use and technology leadership of Texas high public schools and headteachers. (Unpublished doctoral dissertation). University North Texas. Retrieved June 23, 2013 from http://www.lib.umi.com/dissertations/preview/3214502

15. Yu, C., \& Durrington, V. A. (2006). Technology standards for school administrators: An analysis of practicing and aspiring adminstrators' perceived ability to perform the standards. NASSP Bulletin, 90(4), 301-317. 